\title{
Contending Issues in the Management of Intergovernmental Relations in the Nigerian Federal Administration System
}

\author{
Inyang, Bassey \\ Centre For General Studies, \\ Cross River University Of Technology, Calabar \\ Email:basseyinyang70@yahoo.com
}

\section{Doi:10.5901/mjss.2014.v5n3p226}

\begin{abstract}
Intergovernmental Relations (IGR) is the interaction that takes place among different levels of government within a country. State governments are independent within constitutional limitations of the centre while local governments are subordinated to the states. Usually, the concept is mostly associated with states having a multi-ethnically segmented administrative system like Nigeria where relationship between the Federal and the major component units are formally spelt out in the constitution. A full analysis of IGR must cover Federal-State-Local, Federal-State, Federal-Local, Inter-State, State-Local, and Inter-Local relations enshrined in the constitutional framework. The main issues given prominence in the study of IGR, are the allocation of jurisdictional/constitutional powers, administrative/political mechanisms, and intergovernmental fiscal relations. This paper attempts to examine each of these issues in turn highlighting the increasing dependence of the states and Local Governments on the Federal government and the ubiquity of Federal Government in areas considered an exclusive pressure of the state and local government. It also draws the attention to worthwhile lessons that Nigeria could learn from the experiences of its operation in a federal administration system.
\end{abstract}

Keywords: Federalism, Agitation, Conflicts, Resource Allocation, Jurisdiction.

\section{Introduction}

Federalism is all about sharing, that is, the sharing of powers, functions or responsibilities and resources among levels of government. In the view of Wheare (1963:10), Federalism or "the Federal Principle" is the method of dividing powers so that the Federal or State Governments are each, within a sphere, co-ordinate and independent". Federal unions are informed and sustained, among other forces, by the pressures of "unity in diversity" or by the mutually contradictory motives which Watts (2000:2) refers to as "the desire to build an efficient and dynamic modern state and the search for identity or regional distinctiveness".

Inter-governmental consultation, cooperation, competition and conflict which cut across the formal inter-tier division of powers in which one tier is neither willing or able to ignore the other as they interact co-operatively and conflictingly seem to be the hallmarks of modern federal governments. Other recent writers, unanimously agreeing that there is no pure federal model, have further clarified the concept of federalism than was envisioned by Wheare. Variously, they have observed that federalism implies some form of decentralization, regionalism, administrative cooperation or "co-operative federalism", political interdependence and some form of co-operation, bargaining and conflict (Watts 2000:5; Awa 1976:1-10).

Federalism and intergovernmental relations are inter-related, but they are not the same thing. Because the study of federalism at its immediate empirical level heavily stresses the study of intergovernmental relations, the two are therefore more often considered to be synonymous. Federalism concerns with the way in which federal principles influence party and electoral systems in federal politics just as much as it concerns the way in which local government relate to their states and national ones, or to each other.

The purpose of intergovernmental relations therefore, either on the national, state or international level, is to promote co-operation, co-existence, friendship and détente between governments. It has become acceptable in all federations that the citizens could be best served if all levels of government consulted with each other. Toward this end, most federal systems have set up permanent machineries for inter-governmental and Federal-State-Local Governments Co-operation.

Finally, in many federations, through judicial interpretations, the courts have successfully barred all levels of 
government from performing certain functions. It is only by cooperation that such loose ends can be tightened up. Cooperative theorists hold that federalism is an association of diverse groups interacting cooperatively with one another in a circular form through layers of government with the objective of satisfying their respective local, regional and foreign interest without recourse to strict local, state and national differentiation. It goes without saying that the nature of FederalState-Local Government relations - a short hand notation for Federal-State-Local, Federal-State, Federal-Local, StateState, State-Local and Local-Local relationships according to Akinsanya (1998:3), is contingent upon the formal division of powers among levels of government enshrined in the constitutional framework.

\section{Allocation of Jurisdictional/Constitutional Powers in Inter-Government Relations}

Intergovernmental relations is the term commonly used to describe the interactions between the different levels of government within a state. Although the word "level" implies a juxtaposition of higher and lower levels, there is strong support in the literature for emphasizing cooperation among the levels of government and deemphasizing the idea of a hierarchical relationship. In federal systems, intergovernmental relations are dominated by the relationship between the central government and the major component units with the main features spelled out in the constitution. In particular, the jurisdictional powers of each level of government are delineated in the constitution amendment involving both levels of government. Although the emphasis in the analysis of intergovernmental relations is on federal-state relations, the full picture also includes how both levels relate to the local governments established within the states.

According to Adamolekun, (2002:61), the allocation of jurisdictional powers among the levels of government is a major issue in analysing any intergovernmental relations system. Although the federal-state level is most often considered the most critical, increased attention is being paid to functional allocations related to federal-state-local, federal-local, and state-local levels. For the federal-state level, there are three possible approaches. The first is that the 1999 constitution of the Federal Republic of Nigeria contains the Exclusive Legislative list comprising 68 Articles, that is, items on which only the National Assembly is conferred with the power to make laws for peace, order and good government of the Federal Republic of Nigeria or any part thereof on any matter included in the Exclusive Legislative list set out in Part 1 of the second schedule of this constitution. The second is that the second schedule of the constitution contains the Concurrent Legislative list comprising thirty Articles in Part II over which the State Assembly may make laws. But Section 4(5) provides that if a State law is inconsistent with a federal law, the former shall become null and void to the extent of its inconsistency (CFRN: 1999:136-138). Thus, State laws in respect of concurrent legislative list could always be countermanded by federal primacy or superiority. Thirdly, the residual legislative list are items not included in the exclusive legislative list nor the concurrent legislative list and are left for the State to legislate upon. But there is no residual legislative list over which exclusive legislative powers are vested in the state and local governments.

Given these wide-ranging powers of the National Assembly, and the fact that 118 out of 320 provisions of the constitution are on the powers of the President - a development that makes the Nigerian President the most powerful President in the world, including the president of the United States of America, the 1999 constitution has been described as "the equivalent of a constitutional dictatorship" or as a "unitary constitution coated in federal garb" or what Akindele, (1994:2) dubbed "unitary country in a federal union".

Therefore in a federal state, the machinations for regulating relationship among the units and the centre are to be founded in the constitutional sharing powers. The authority to legislate for the entire country resides with the National Assembly. The 1999 constitution while guaranteeing a system of democratically elected local government also empowers every state, subject to section 8 of the constitution to ensure "their existence under a law which provides for the establishment, structure, composition, finance and functions of such council". However, there can be little doubt of the trend towards increasing Federal Authority if not supremacy in this matter. The 1999 constitution like many others is a product of military government. It does not truly represent federal arrangement. It allows the centre to play dominant role over component units. And so, whose baby is the local government? The Federal or State government? (Oyeyipo, 1980:255).

The creation of local government is left at the hands of state government. Therefore, relationship among the units according to the constitutional provisions indicate that while federal government "Lord" over State Government, the State Government in turn is empowered to dominate the Local Government. The domineering role of the State Government over the Local Government in Nigeria could best be described using Professor Akinsanya's (1997:97) assertion that "The relationship between the State and Local Government(s) is a superordinate subordinate relationship. What seems to have compounded the dilemma of local Government as effective third tier system of government is the power exercised by new local government areas and removal of council Chairman from office". 
Adewunmi, (1983:275) was more blunt when he asserted that; "Local Government is a state subject". This reference is not just subjugatory but explains the kind of relationship that exists between the government of the federation and the state government on one hand and the Local Government on the other.

\section{Administrative Mechanisms for Managing Intergovernmental Policy Coordination}

Managing intergovernmental relations relies on a variety of political and administrative mechanisms as well as the judicial process. The preeminent political mechanism is the constitution, which spells out the legislative powers conferred on each tier of government. In addition to the legislative process, there are four existing administrative structures which include the National Council for Economic Planning which brings together the head of State and the state governors as members. This Council is essentially a consultative forum, where issues of concern to the federal and state governments are discussed. There is the National Council on Development Planning with a membership of State Commissioner for Planning. Then the Joint Planning Board in which states are represented at the level of Permanent Secretaries from respective planning ministries and the National Sectoral Councils in all key sectors, representing respective state sectoral ministers and in which the National Planning Commission (NPC) is also represented.

A number of the administrative consultative forums bring together senior policy makers at the federal and state levels, for example, conferences of Accountants General, and the conferences that bring together Ministers and Commissioners in such area as finance, education and agriculture. These consultative bodies enable the officials of state and federal governments to explore sectoral issues and offer advice to the federal and state governments. A National Council on IGR was established for a brief period (1992-1996) to conduct studies, promote exchange of information, and provide advice on intergovernmental issues.

The use of conferences are effective that almost all professional groups across governmental levels are held on daily basis. Such groups include Speakers of State Houses of Assembly, Local Government Chairmen meetings, Association of Local Government of Nigeria (ALGON) and state governors meetings. There is also monthly consultative/allocation meeting between the executive arm of the state and the local government chairmen and key government functionaries.

The administrative mechanisms for managing intergovernmental relations are basically those institutional agencies across different levels of government used to implement intergovernmental relations policies and actions. According to Adamolekun, (1983:89) the administrative mechanism for IGR in Nigeria is dominated by federal-state and interstate conferences. Between 1980 and 1990, over 2000 conferences and meetings were held at the federal-state and interstate levels. During Shagari regime, bi-annual conferences of commissioners for local government were held with units in the President's office as the secretariat. At the head of each of these institutions, is a top official of the relevant ministry usually the permanent secretary. The state may have one or two representatives, a few individuals may be co-opted from such bodies as the Nursing Council of Nigeria, the Midwives Board and the Nigerian Medical Council.

In administrative matters, Federal-State-Local relations have moved in the direction of federal assertive leadership and control. Numerous intergovernmental administrative institutions have been created extensibly to provide avenues of Federal-State consultation and co-operation, but actually to provide additional pressure points for integration and Federal dominance. One of such administrative institutions with a number of tentacles is the Nigerian Council for Science and Technology established by Decree No. 6 of 1970. Created to determine priorities for scientific activities in the federal, advice on a national policy, conduct research and advise on the application of research, the Council of Science and Technology maintains general surveillance of a number of Research Councils. The latter include the Medical Research Council of Nigeria (1972), the Agricultural Research Council (1971) the Indusial Research Council (1971) and the Natural Sciences Research Council (1971) and the Natural Sciences Research Council (1973). Each Council in turn has its own institutions for research promotion and co-ordination. It has been observed that these councils are doing their best. But to the extent that each state is represented on these councils and that these meet regularly, to the extent with national, rather than parochial outlook develop to further strengthen integration and federal leadership and dominance.

There are also intergovernmental and interstate institutions established within Federal Ministries to co-ordinate certain common activities. The Cooperative and Social Development Divisions of the Federal Ministry of Labour are typical. These divisions are advised by an Advisory Council of Federal and state officials. In theory, this arrangement provides opportunities for the state officials to make the best case for their respective states, but in practice, the reverse is true. The same opportunities are opened to the federal officials to make their case and they have the additional authority of their Ministry, as the sponsoring agent to wield great influence. The proliferations of such new institutions under a new breed of officials are bound to enhance national outlook and strengthen federal hands. The same could be 
said of the mushrooming bilateral authorities established by the federal government for the promotion of land and water development in order to increase agriculture and fish production. The activities of the Chad Basin and Sokoto Rima Basin Authorities have the effect of increasing federal grants to the component states. As such, they are integral functional equivalent of the ordinary federal grants to states for emergency relief and social developments, and perform the same function and provide avenue to influence and control state policy.

Inter-governmental administrative relations in Nigeria over the years have experienced serious and detrimental competitions between the Federal Government and the component states of the federation. One of the many causes of Nigeria political instability is diversity. The fragmentation and the social differences are enormous and the effort to level them together in itself becomes a problem. According to Adamolekun (1983), the observation made about the preference of the political actors has resulted in a situation in which the cooperation and combination implicit in the federal arrangements provided for in the constitution have been replaced by competition, conflict and confrontation". In fact, the states through whom local governments received their funds were starved for fund. It became worst if the local government does not belong to the ruling party at the national and state levels. This largely accounted for why most local governments at this level performed below expectation. It is of parenthetical interest to see how Federal-State-Local relations have been in Obasanjo's administration which operates the "doctored" 1979 constitution now called the 1999 constitution of the Federal Republic of Nigeria.

In all, these existing administrative arrangements for policy coordination between the federal and state governments remain quite weak. Effectiveness of national sectoral councils is low, and they are seen by many as just "talking shops and paper exercise" for participating officials. The key indication of existing weaknesses in current coordination arrangements relates to the fact that Nigeria does not have an established system for the production of consolidated national reports on performance in individual sectors. A lack of information on outcomes and outputs undermines the whole concept of planning and coordination. Planning without monitoring and evaluation cannot be productive (Freinkman, 2007).

\section{Intergovernmental Fiscal Relations}

Unarguably, fiscal federalism is the whole idea of how money is raised through taxation, and spent through appropriation which is usually one of the most contentious issues in federal systems. Fiscal federalism concerns the division of public sector functions and finances among different tiers of government (Ozo-Eson, 2005:1) No where is the emergence of federal supremacy better reflected than fiscal relations. A federal fiscal system comprises of two parts. IGR Tax Jurisdiction and IGR Revenue Allocation. While the first pertains to the legal basis of levying taxes, the latter pertains to the distribution of the revenue amongst the tiers of government (Fajana, 1980:179).

In the years before 1976, the component states of the federation were, in manner of speaking, fiscally selfsufficient. This can be seen when the current revenue of the regional and federal governments are compared. It was no wonder the regions were so powerful vis-à-vis the federal government and a federal-state confrontation ended in the 1966 disaster. After 1968, however, the trend was reversed. Between 1968 and 1974 federal revenue increase by $293.3 \%$ whereas those of the states put together rose by only $214.5 \%$. Moreover, where the rate of revenue growth of each and every region has surpassed that of the Federal Government in the years before 1966, during the 1968-1974 period, only a third of the twelve states had a higher revenue growth rate.

The need for balance and uniform economic development and, indeed, the maintenance of a uniform level in the provision of services has meant that the federal government has to administer disproportionate amount of aid to the power state, and this has implied, rather unfortunately, an increasing overall control by the federal government. This is much to be expected since he who pays the piper dictates the tune. Additionally, the tendency towards centrally-planned economy and the increasing use of the budget as an instrument of financial and economic control have rendered the judicial interpretation of federalism more and more unrealistic. The provision of social welfare is now largely controlled by the federal government and financed from federal sources although this was an area originally reserved to the states by the constitution.

In a federal system of government, the issue of financial relations is always very explosive. As a result, it always attract to itself an unprecedented attention. Issues concerning the appointment of centrally collected financial revenue and taxing powers vested in each tier of government, in short, fiscal federalism, are a salient aspect of Nigeria's public administration. Revenue Allocation is a crucial issue because the federal government levies and collects a variety of taxes on behalf of the whole country. These revenues go into the pool called the Federation Account. The sharing of the revenue from the federation account is based on what is called the Federal Revenue Allocation Formula. The adoption of 
a new revenue allocation formula has most often, though not always, been preceded by the establishment of a revenue allocation commission. A permanent body called the National Revenue Mobilization, Allocation and Fiscal Commission was established in 1989 and entrusted with the responsibility for advising the government on measures for revenue allocation and mobilization. The revenue allocation formula in force since June 1992 gives 48.5 per cent of the federation account to the federal government, 24 percent to the state government, 20 percent to the local governments and 7.5 percent as special fund that is distributed for such purposes as ecology, development of oil mineral producing areas, and Federal Capital Territory.

The federal government introduced the value-added tax (VAT) as an additional source of revenue in 1994. The formula for the distribution of VAT has been reviewed several times and as of 1998 was 25 percent to the federal government, 45 percent to the state governments and 30 percent to the local governments. The taxing powers conferred on each tier of government by the constitution and amended by subsequent laws have led to overlapping taxing arrangements. To reduce the incidence of multiple taxes for all tiers of government, a new scheduled of taxes was published in April 1997. According to the schedule, the federal government is empowered to collect company income tax, petroleum profit tax, VAT, education tax, capital gains tax, stamp duties of corporate entities and personal income taxes from personnel of the armed forces, foreign affairs, police and residents of the federal capital territory of Abuja. The state governments will collect personal income tax, capital gains tax, stamp duties from individuals, road taxes, development levy, business premises and registration levy. Local government will collect levy on shops, kiosks, slaughter fees, marriage, birth and death fees, motor park fees, cattle tax, radio and television tax and advertisement tax.

Revenue allocation problems have constituted, perhaps, the most teething problems for the Obasanjo and Yar'Adua's administration, which failed to take a number of actions on revenue matters, sometimes touching off acts of provocation. Section 162 (2) of the 1999 CFRN has a proviso which enjoins the National Assembly to take into account certain allocation principles such as "Derivation" while prescribing the formula for the distribution of money in the Federation Account (The Guardian, 14 August 2000:8). Although controversial, the constitution allows the derivation figure at $13 \%$ of the total revenue accruing to the federation account directly from any natural resources, specifically, oil revenue. The $13 \%$ derivation allocation is just to the oil producing states. This is done on the basis of oil revenue each state contributes to the federation account in addition to the states normal allocation. The $13 \%$ cited in section 162 (2) is a benchmark-the irreducible minimum allowable on derivation. The actual formula should be settled and it is the president who must lead the ways. See table III for sharing derivation fund.

When Obansanjo's administration came on board, it failed to implement the $13 \%$ derivation principle in respect of revenue accruing to states where natural resources are located in conformity with section 162 (2) of the 1999 constitution. After much pressure from the oil-producing states, this administration, manufacturing or resuscitating, without any supporting law, the obnoxious on-shore/offshore dichotomy whose ghost even the much vilified SanniAbacha administration had in 1992 laid to rest, arbitrarily decided to pay $7.8 \%$ or $(60 \%)$ of the $13 \%$ while withholding $5.2 \%$ or $(40 \%)$ which the administration estimated to be the off-shore component. Again payment of the $7.8 \%$ was from January 2000 instead of $29^{\text {th }}$ May, 1999 when the constitution became operative. The oil producing states have made sustained fruitless entreaties in an effort to get the Federal Government to pay them the arrears of the $13 \%$ derivation fund. There is therefore partial and half-hearted implementation by the Federal Government of the $13 \%$ derivation.

On the other hand, states considering that the current revenue allocation formula (Federal $48.5 \%$, states $24 \%$ local government $20 \%$ special fund $7.5 \%$ ), puts too much money in the hands of the federal government, have proceeded to propose a more equitable distribution of revenue among the federal, state and local governments such that less money should go to the federal, and more to state and local governments. The proposed revenue allocation formula of $25 \%$ to federal, $45 \%$ to state, $25 \%$ to local government, $3 \%$ to ecological funds, and $2 \%$ to other matters by the South-South States is a case in point. (Sunday Guardian, 16 July 2002:2).

The allocation of funds from the Federation Account by the Ministry of Finance at times by the National Assembly, rather than the National Revenue Mobilization, Allocation and Fiscal Commission which has the statutory responsibility for carrying out such allocation under section 162 of the 1999 constitution is considered illegal, unconstitutional and lacking in transparency and accountability, apart from being unfair to other tiers of government which, alongside the federal government, are also beneficiaries of funds accruing to the federation account. In recent times, federal government's control of the federation account has been criticized.

The benefits of recent fiscal decentralization have been distributed rather unevenly across sub-national governments. This is because, in keeping with the constitutional arrangement about a third of all allocations from the federation account to states reflects derivation-oil payments, which are heavily concentrated. The four main oil-producing states (Rivers, Bayelsa, Delta and Akwa Ibom) jointly received about 90 percent of all derivation oil payments or about 
N265 billion (\$ US 2 billion) in 2005. So far, fiscal decentralization in Nigeria has not been accompanied by strengthened accountability of sub-national government for efficient utilization of resources they have now in their disposal. This complicates progress in improving service delivery. Tables I-III are summary of the evolution of revenue commissions and allocation formulas in Nigeria from 1946 - 2005.

\section{A Brief Historical Outline of Revenue Allocation Formulas in Nigeria}

Table I:

\begin{tabular}{|c|c|c|c|c|c|c|}
\hline Item & Date & Federal Gov. \% & State Govt \% & \begin{tabular}{|l|} 
Local \\
Govt. $\%$
\end{tabular} & $\begin{array}{l}\text { Special } \\
\text { Funds }\end{array}$ & Total \\
\hline $\begin{array}{l}\text { Philipson } \\
\text { Commission }\end{array}$ & 1946 & & $\begin{array}{c}\text { Largely by Derivation Northern Region } 46 \% \\
\text { Western Region 30\% } \\
\text { Eastern Region } 24 \%\end{array}$ & & & \\
\hline $\begin{array}{l}\text { Hicks-Phillipson } \\
\text { Report }\end{array}$ & 1951 & & By Derivation need \& national interest & & & \\
\hline Chick Commission & 1953 & $F G-50 \%$ & Region $50 \%$ & & & \\
\hline $\begin{array}{l}\text { Raisman Tress } \\
\text { Commission }\end{array}$ & 1958 & \begin{tabular}{|c|} 
Introduced Distributable Pool Account \\
(DPA) under Federal control from DPA: \\
$20 \%$ of mining rent and loyalty
\end{tabular} & $\begin{array}{l}\text { From DPA: } 50 \% \text { of mining rent and loyalty } \\
\text { returned to region of derivation. From DPA: } 30 \% \\
\text { of mining rent and loyalty to all other regions }\end{array}$ & & & \\
\hline Binns Commission & 1964 & No fundamental changes & & & & \\
\hline $\begin{array}{l}\text { Federal Military } \\
\text { Decree } 15\end{array}$ & 1967 & (states created May 27, 1967 & $\begin{array}{c}\text { DPA divided equally among } 6 \text { Northern States, } \\
\text { by population among Southern States. }\end{array}$ & & & \\
\hline Dina Commission & $\begin{array}{c}1969 \\
\text { (rejected) }\end{array}$ & \begin{tabular}{|c|} 
DPA renamed states Joint Account \\
SJA) and a special grant accounts \\
(SGA). Allocation of funds based on tax \\
efforts, balanced devt. And national \\
interest.
\end{tabular} & $\begin{array}{c}\text { Offshore operations revenue shared FGN 60\% } \\
\text { SJA, 30\% \& SGA, 10\% Onshore Royalties } \\
\text { shared FGN 15\%, State of derivation 10\%; SJA } \\
70 \% \text { and SGA 5\%. }\end{array}$ & & & \\
\hline $\begin{array}{l}\text { Federal Military } \\
\text { Decree } 13\end{array}$ & 1970 & No fundamental changes & & & & \\
\hline $\begin{array}{l}\text { Federal Military } \\
\text { Decree } 6\end{array}$ & 1975 & $\begin{array}{c}\text { DPA } \\
-80 \% \text { of mining rents and royalties } \\
-35 \% \text { of import duties, } \\
-100 \% \text { of duties on motor spirits etc } \\
-50 \% \text { of excise duties } \\
\end{array}$ & $\begin{array}{l}\text { DPA be divided among the states as follows:- } \\
50 \% \text { based on equality of states } 50 \% \text { based on } \\
\text { population }\end{array}$ & & & \\
\hline $\begin{array}{c}\text { Abayode } \\
\text { Commission }\end{array}$ & 1977 & 57.00 & 30.00 & 10.00 & 3.00 & 100.00 \\
\hline $\begin{array}{c}\text { Okigbo } \\
\text { Commission }\end{array}$ & 1980 & 53.00 & 30.00 & 10.00 & 7.00 & 100.00 \\
\hline $\begin{array}{c}\text { Revenue } \\
\text { Allocation Act }\end{array}$ & 1981 & 55.00 & 30.50 & 10.00 & 4.50 & 100.00 \\
\hline $\begin{array}{c}\text { Pre-Supreme } \\
\text { Court - RMAFC } \\
\text { Proposal } \\
\end{array}$ & August 2001 & 41.23 & 31.00 & 16.00 & 11.70 & 100.00 \\
\hline $\begin{array}{l}\text { Pre-Supreme } \\
\text { Court-Legal } \\
\text { Decree/Law } \\
\end{array}$ & 2002 & 47.50 & 24.00 & 20.00 & 7.50 & 100.00 \\
\hline $\begin{array}{l}\text { Supreme Court } \\
\text { Ruling }\end{array}$ & April 2002 & & Unconstitutional & & & \\
\hline $\begin{array}{l}\text { Post Supreme } \\
\text { court Executive } \\
\text { order No. } 1\end{array}$ & $\begin{array}{l}\text { May } \\
2002\end{array}$ & 56.00 & 24.00 & 20.00 & 0.00 & 100.00 \\
\hline $\begin{array}{l}\text { Post-Supreme } \\
\text { Court Executive } \\
\text { order No } 2\end{array}$ & July 2002 & 54.68 & 24.72 & 20.60 & 0.00 & 100.00 \\
\hline $\begin{array}{l}\text { Post-Supreme- } \\
\text { Court RFMLC } \\
\text { Proposal }\end{array}$ & January 2003 & 46.63 & 33.00 & 20.37 & 0.00 & 100.00 \\
\hline $\begin{array}{l}\text { Latest RFMAC } \\
\text { Proposal }\end{array}$ & $\begin{array}{l}\text { Submitted to } \\
\text { president } \\
\text { 20/09/2004 } \\
\end{array}$ & 47.19 & 31.10 & 15.21 & 6.50 & 100.00 \\
\hline $\begin{array}{l}\text { Presidential } \\
\text { Proposal }\end{array}$ & $\begin{array}{l}\text { Submitted to } \\
\text { NASS } \\
25 / 01 / 2005 \\
\end{array}$ & 47.19 & 31.10 & 15.21 & 6.50 & 100.00 \\
\hline
\end{tabular}


Table II: Horizontal Formulas for Distributing Revenue

\begin{tabular}{|l|c|c|}
\hline \multicolumn{1}{|c|}{ Item } & To states & To LGs \\
\hline \% from FG & 31.10 & 15.21 \\
\hline Equity & 45.23 & 0.00 \\
\hline Population & 25.60 & 30.83 \\
\hline Population density & 1.45 & 6.45 \\
\hline Internal Revenue & \multicolumn{2}{|l|}{} \\
\hline Generation Effort & 8.31 & 13.31 \\
\hline Land Mass & 5.35 & 10.35 \\
\hline Terrain & 5.35 & 10.35 \\
\hline Rural Roads and Inland & 1.50 & 6.50 \\
\hline Waterways/Portable water & 3.00 & 8.00 \\
\hline Education & 3.00 & 8.00 \\
\hline Health & 100.00 & 100.00 \\
\hline Total & \multicolumn{2}{|l}{} \\
\hline
\end{tabular}

Table III: Sharing of 13\% Derivation Fund (to be Managed by States Derivation Fund Boards)

\begin{tabular}{|l|c|l|}
\hline \multicolumn{1}{|c|}{ ITEM } & 13\% Derivation: Percentage Shared & \multicolumn{1}{c|}{ Basis of Sharing Among Entities } \\
\hline To States & 60.00 & Relative to Quantum of Production \\
\hline To Local Government & 30.00 & $50 \%$ quantum; 20\% equality; 20\% population 10\% self-help projects \\
\hline To community & 10.00 & To be specified according to relevant Assembly House or National \\
\hline Total & 100.00 & \\
\hline
\end{tabular}

\section{Conclusion and Recommendations}

If the administration of the Nigerian Government in recent past had been a failure, the blame does not belong to the local unregenerated, crude politicians, whose main goals and aspirations are to control power and authority at all cost; nor does the blame belongs to the innocent, uneducated, uninformed citizens who do not know their left from right and position in the society. The blame and failure belong to the educated, political and social elites, who have been carried away by their own egocentric ideas and have turned their backs on their obligations as leaders.

Problem associated with fiscal federalism, the agitation for the restructuring of the federation of Nigeria in order for "true federalism" to emerge, have tended to dominate the present administration. Intergovernmental fiscal relation is not a smooth process, as such all stakeholders must be committed to fine-tune the process in the overall interest of the country. One has to admit the fact that intergovernmental fiscal relations in a federal set up, belong to the watershed between economics and politics, therefore, while economist carry out the basic analysis that could facilitate decision making, the percentages going to the tiers of government as well as the distribution amongst states and local governments should be left to the policy makers.

Ironically, therefore, the so-called democratic dispensation is still overly "quasi federalism in operation", still the equivalent of a constitutional dictatorship in many respects and still a "unitary country in a federal disguise". This is so because elements of unilateralism closely associated with militarism in the governance of the country in the past few decades seem to be perpetuated under Obasanjo and late Yar'Adua's regimes, accounting for much of the opposition from states and local governments, sometime overheating and tending to destabilize the system. Only "true federalism" as clearly demanded by Nigerians of all hues will engender prosperity, peace, happiness and harmonious co-existence of all Nigerians in the $21^{\text {st }}$ century. But whether Nigeria remains a federation or not depends, among other things on the sharing and distribution of power and resources in the country. Federal-State-Local relations in the Nigerian intergovernmental system should be to facilitate mutual sharing of functions and to encourage equal participation of the citizens in the affairs of their country. The existing system of sharing the common pool of funds need careful and gradual transformation to provide for more equalization dimension of federalism and the introduction of new financing mechanisms, such as federal matching, conditional and specific grants to states and the strengthening of accountability arrangements for spending public money. Finally, development partners could support Nigeria's effort by helping the federal government to carry out unbiased evaluation/monitoring of state performance and providing advice of the best international practice in the organization of intergovernmental fiscal relations. The intractable problems arising from the 
widely unacceptable and constant conflicting fiscal federalism in Nigeria as seen in tables I - III above, need urgent correctible measures. There is also the urgent need for constitutional review especially as it relates to federalism. The time is act is now.

\section{References}

Adamolekun Ladipo (1983) Public Administration. A Nigerian and Comparative Perspective. Lagos: Longman Group Ltd.

Adamolekun, Ladipo (ed.) (2002) Public Administration in Africa: Main Issues And Selected Country Studies. Ibadan: Spectrum Books Ltd.

Adewumi, J. B. (1983) Central-Local Government Relations. Benin: Ethiope Publishing Corporation.

Akindele, R. A. (1994) "The Conduct and Management of Intergovernmental Relations: The Limits of Information and Experience. Sharing by Students of Federalism and Students of International Affairs" in The Nigerian Journal ofFederalism 1 (2).

Akinsanya, Adeoye (1998). "Intergovernmental Relations in Nigeria under the 1995 Draft Constitution", in Uya, Okon and Uchendu, Victor (eds) Issues in the 1995 Draft Constitution. Calabar. CATS Publishers.

Akinyemi, A. B. (2004) Federalism, Intergovernmental Relationship, Partisan Politics and Development: A Critical Assessment of Nigeria (1999-2004) A Paper Delivered at the First Intergovernmental Quarterly Roundtable on Development held in Lagos.

Awa, E. O. (1976) Issues in Federalism. Benin City: Ethiope Publishing Corporation.

Constitution of the Federal Republic of Nigeria (CFRN) (1999) Apapa - Lagos: Federal Government Press.

Ekpo, A. H., (2004) Intergovernmental Fiscal Relations: The Nigerian Experience. A Paper Presented at the 10th Year Anniversary of the Financial and Fiscal Commission of South Africa, Cape Town: South Africa.

Eme, I. E. (2002) Politics for Non-Politicians: A Contemporary Nigerian Government and Politics. Calabar: Franedoh Publishers (Nig) Ltd.

Eminue, O. (2002) Federal-State-Local Government Contending Issues in Nigerian Federalism in Okon E. Uya (eds) Local Government Administration and Grassroots Democracy in Nigeria Calabar: University of Calabar Press.

Fajana, O. (1980) Intergovernmental Fiscal Relations in the Report of the Technical Committee on Revenue Allocation. Quarterly Journal of Administration. January 1980.

Freinkman, Lev. (2007) Intergovernmental Relations in Nigeria: Improving Service Delivery in Core Sectors. The World Bank, April.

Ojo, O. J. B. (1976) Federal-State Relations. Quarterly Journal of Administration (1976-1974).

Oyeyipe, E. O. (1980) Federal-State-Local Relations. Quarterly Journal of Administration. January 1980.

Ozo-Eson, (2005) "Fiscal Federalism: Theory, Issues and Perspectives". Daily Independent.

Shah, Anwar (eds) (2007) "A Practitioner's Guide to Intergovernmental Fiscal Transfers" in Broadway and Shah (World Bank. Washington DC).

Uya, O. E. and Uchendu, V. (1999), Issues in the 1995 Nigerian Draft Constitution. Calabar: CATS Publishers.

Watts, Ronald (2000). "The Contemporary Relevance of the Federal Idea". African Journal of Federal Studies 1 (I) p. 2.

Wheare, Kenneth C., (4th ed.) (1963) Federal Government. London: Oxford University Press.

World Bank (2007) Nigeria: A Fiscal Agenda for Change. PEMF. 